\title{
Fat and Bone: An Odd Couple
}

\author{
Richard Kremer ${ }^{1 *}$ and Vicente Gilsanz ${ }^{2}$ \\ ${ }^{1}$ McGill University, Montreal, QC, Canada, ${ }^{2}$ Children's Hospital Los Angeles, Keck School of Medicine of the University of \\ Southern California, Los Angeles, CA, USA
}

In this review, we will first discuss the concept of bone strength and introduce how fat at different locations, including the bone marrow, directly or indirectly regulates bone turnover. We will then review the current literature supporting the mechanistic relationship between marrow fat and bone and our understanding of the relationship between body fat, body weight, and bone with emphasis on its hormonal regulation. Finally, we will briefly discuss the importance and challenges of accurately measuring the fat compartments using non-invasive methods. This review highlights the complex relationship between fat and bone and how these new concepts will impact our diagnostic and therapeutic approaches in the very near future.

Keywords: bone, fat, imaging, vitamin D, marrow fat, MRI, hormones

\section{INTRODUCTION}

OPEN ACCESS

Edited by:

Basem M. Abdallah, University of Southern Denmark, Denmark

Reviewed by: Katherine Brooke-Wavell, Loughborough University, UK Chantal Chenu, Royal Veterinary College, UK

*Correspondence: Richard Kremer richard.kremer@mcgill.ca

Specialty section: This article was submitted to Bone Research, a section of the journal Frontiers in Endocrinology

Received: 25 February 2015 Accepted: 14 December 2015 Published: 07 March 2016

Citation: Kremer R and Gilsanz V (2016) Fat and Bone: An Odd Couple.

Front. Endocrinol. 6:190. doi: 10.3389/fendo.2015.00190
We will briefly review how the definition of osteoporosis has evolved to integrate other parameters in addition to bone mineral density (BMD) measurements. We will then review the makeup of the bone microenvironment and the distribution of fat within and outside the bone compartment. Finally, we will briefly summarize how muscle and its fat composition may have impact on bone strength.

\section{The Concept of Bone Strength}

At the National Institutes of Health (NIH) Consensus Conference in 2000, osteoporosis was defined as a skeletal disorder characterized by compromised bone strength that predisposes to an increased risk of fracture (1). Bone strength reflects the integration of two features: BMD and bone quality. $\mathrm{BMD}$ is one of the strongest risk factor for fractures and its measurement has long been used to define osteoporosis. Clinical risk factors have also been integrated with BMD measurements in an attempt to help clinicians better identify patients requiring osteoporosis therapy (2). The FRAX calculator is a user-friendly web-based tool that provides immediate quantification of risks and treatment decision making based on a very simple algorithm. However, it should always be interpreted within the clinical context as it does not take into account a number of important clinical variables.

The World Health Organization defines osteoporosis as two and a half SD below the peak bone mass [i.e., the maximum amount acquired post bone maturation around the age of 18 in women (3) and 20 in men (4), but bone growth can continue up to the age of 30]. It is expressed as grams of mineral per area or volume. On the other hand, bone quality reflects a combination of bone microarchitecture, bone turnover, and mineralization. Peak bone mass is therefore a critical parameter that will impact bone strength as the skeleton is aging. Genetic factors appear to account for over $50 \%$ of the variation in peak bone mass acquisition (5). As bone is progressively lost overtime, the higher the peak bone mass, the longer the skeleton could theoretically withstand damage. This progressive bone loss from peak bone mass occurs predominantly as a result of reduced bone formation from osteoblast $(6,7)$ and resultant protein composition (8) and persists for decades thereafter. Additionally, accelerated bone resorption predominates in women as a result of estrogen deficiency 
at the menopause but also to a lesser extent in men after the fifth decade (6). However, postmenopausal women have the ability to produce estrogens from the peripheral conversion in fat tissues of testosterone to estradiol. Adipocytes indeed express the cytochrome $\mathrm{P} 450$ enzyme, aromatase, which can produce estradiol from testosterone. This peripheral production of estradiol has been proposed as a protective mechanism against bone loss in overweight women (9-11).

Bone strength is highly dependent on its structural and material properties. The balance between bone formation and resorption, also called bone turnover, greatly influences the material properties of bone such as tissue mineral density and collagen cross-linking. Enhanced bone turnover, as seen with a lack of estrogen in postmenopausal women, influences the structural and material properties that lead to bone microdamage. With aging, the reduction in bone strength is further compounded by progressive muscle weakness and the increased risk for falls due to lack of balance and coordination. Maintenance of bone mineralization within a relatively narrow range is also critical to the maintenance of bone strength (12). Poorly mineralized bone loses its stiffness, whereas excessive mineralization makes bone more brittle. Bisphosphonates, the most widely used drugs to treat osteoporosis by excessive bone turnover, also lead to increased mineralization and stiffness overtime. Impairment of microdamage repair is another potential side effect of bisphosphonates since normal bone turnover replaces old bone with new bone and protects against microdamage. Long-term use of bisphosphonates has been linked to atypical fractures, and one could hypothesize that the combination of abnormal mineralization and reduced turnover may play a role in its development.

\section{The Components of the Bone Microenvironment}

The bone microenvironment is comprised of several compartments, including hematopoietic cells, bone cells, and stromal cells (13). Bone cells, also referred to as the bone remodeling unit (BMU), are composed of bone-forming osteoblasts, boneresorbing osteoclasts, and osteocytes embedded within the bone matrix. The BMU is also in close contact to stromal elements of the marrow and the blood vessels supply (14). Osteoclasts are of hematopoietic origin, whereas osteoblasts originate from bone marrow mesenchymal stem cells (MSCs) $(11,14,15)$. One of the most interesting occurrences in this environment is the accumulation of fat cells during aging and in some pathological conditions. The functional significance of this "marrow fat (MF)" accumulation correlates strongly and inversely with bone strength (16). However, its causal relationship to bone degradation as well as its potential for therapeutic targeting in osteoporosis remains to be determined. There is indeed a significant gap of knowledge in our understanding of the mechanistic relationships between fat and bone especially during the aging process.

\section{The Components and Distribution of Body Fat}

In humans, white adipose tissue (WAT) is principally located beneath the skin (subcutaneous fat) and around internal organs (visceral fat or abdominal fat). The main cellular component of WAT is the adipocyte but other cell types are also present, including fibroblasts, macrophages, and blood vessels. Its main function is energy storage. Adipose tissue also accounts for a significant proportion of the breast tissue and is found around other organs (such as pericardial and gonadal fat) providing protective padding. Adipocytes are also found in small amounts outside adipose tissues, including muscle, liver, pancreas, and heart, which are also referred as ectopic fat. Fat cells are also found in the bone marrow, "MF", and have been the subject of enormous research interest to explore their relationship with the bone microenvironment.

Another form of adipose tissue is known as brown fat or brown adipose tissue (BAT) located mainly around the neck and large blood vessels of the thorax of neonates whose main function is to generate heat and protect neonates against cold (17). Recent studies indicate that BAT is also found in the neck and trunk of adults albeit in lesser amounts (18). Although this review focuses mainly on white fat, the relationship between BAT and bone will be briefly discussed.

\section{Muscle Fat, Muscle Strength, and Bone Strength}

Many studies have clearly demonstrated the positive impact of muscle strength on bone strength, but we will not cover this important area of research here. However, an interesting, but much less explored, area is the relationship between muscle fat and muscle strength and by extension its impact on bone strength. Fat accumulation in muscle may also have indirect effects on bone. Intermuscular adipose tissue accumulation occurs during aging or in pathological conditions such as Duchenne muscular dystrophy, which has been linked to decreased muscle strength, a known risk factor for osteoporosis and fractures (19). Increased intermuscular adipose tissue is associated with poor mobility (20) and increased risk of hip fractures (21). However, it is not yet known whether intermuscular adipose tissue accumulation is simply a marker of muscle dysfunction or has a direct causal effect on muscle function. The relationship between vitamin $\mathrm{D}$ and intermuscular adipose tissue is discussed later in this review.

\section{BASIC UNDERSTANDING OF THE MECHANISTIC RELATIONSHIP BETWEEN MARROW FAT AND BONE STRENGTH}

In this section, the origin, clinical significance, and the factors that influence MF accumulation will be discussed.

\section{Clinical Observations}

As we age, the cortex of the bones become thinner encircling concomitantly larger marrow cavities filled with fat, but whether this is a result of a passive accumulation of fat as bone is lost and marrow space increases or an age-related shift in MSC differentiation with predominant adipogenesis against osteoblastogenesis is difficult to elucidate.

Meunier et al. studied 81 iliac crest biopsies from elderly women and found that bone marrow samples from women with osteoporosis had a pronounced accumulation of adipocytes, 
relative to levels in healthy young subjects (22). Subsequent studies showed increased bone marrow adiposity in postmenopausal women with osteoporosis and a negative association between bone-MF and rate of bone formation (23-25). Investigations using magnetic resonance imaging (MRI) have shown that the accumulation of bone-MF in the vertebral bodies of older women with low bone mass confers an additional risk for compression fracture beyond that associated with low BMD (26). Further support for this notion are data showing an association between exogenous glucocorticoid use and endogenous over production of cortisol and marked bone marrow infiltration by adipocytes with a significant increase in fracture risk (27-29).

Marrow stromal cells isolated from postmenopausal osteoporotic patients express more adipocytic differentiation markers than those with normal bone mass and are more likely to enter an adipocyte than an osteoblast differentiation program (30,31). Fat in bone marrow may also promote bone resorption since marrow adipocytes, much like fat cells elsewhere, secrete inflammatory cytokines capable of recruiting osteoclasts (32).

\section{Role of MSC}

Pluripotent bone marrow MSCs have the ability to become osteoblasts, chondrocytes, myocytes, or adipocytes under the influence of specific cell-derived differentiation factors (33). This process has been well demonstrated in vitro to control the fate of MSC into osteoblasts or adipocytes. This process is bidirectional and considerable plasticity has been observed both in vitro and in vivo in the ability of bone cells to become adipocytes and vice versa. Mechanical stimuli on the skeleton can also modify the differentiation of MSC into the cell lineages responsible for bone and fat formation (34-39) such that increases in bone strain add to increased osteogenic activity, whereas decreases favor the adipogenic differentiation. Lastly, the lack of estrogen in rats following oophorectomy has been reported to lead to profound fatty bone marrow infiltration, suggesting that estrogen must play an important role in regulating adipocyte recruitment (40).

Data from pathological specimens and imaging studies have consistently observed a reciprocal relationship between bone mass and increased marrow adiposity in elderly humans (22, 41-43). A recent study found that the accumulation of MF during aging is linked to increased expression of RANKL, a finding that could explain at least in part age-related bone loss (44). However, whether the relation between these two tissues in the elderly represents the clinical translation of preferential differentiation by MSC into the adipose cell lineage or is merely the unintended consequence of a passive accumulation of adipose tissue as bone is lost and marrow space increases has been a matter of considerable debate. To avoid this confounding effect, young subjects were examined and found that bone acquisition is tightly linked with decreases in marrow adiposity (16). The inverse relation between the amount of bone and MF is observed at all sites along the shaft of the bone in the young and the old regardless of age, gender, or anthropometric measures $(45,46)$ (Figure 1). Moreover, prospective longitudinal studies have found that bone acquisition in the appendicular skeleton of healthy young females is inversely related to changes in marrow adiposity (16). Consequently, one could make a strong argument that during the aging process,

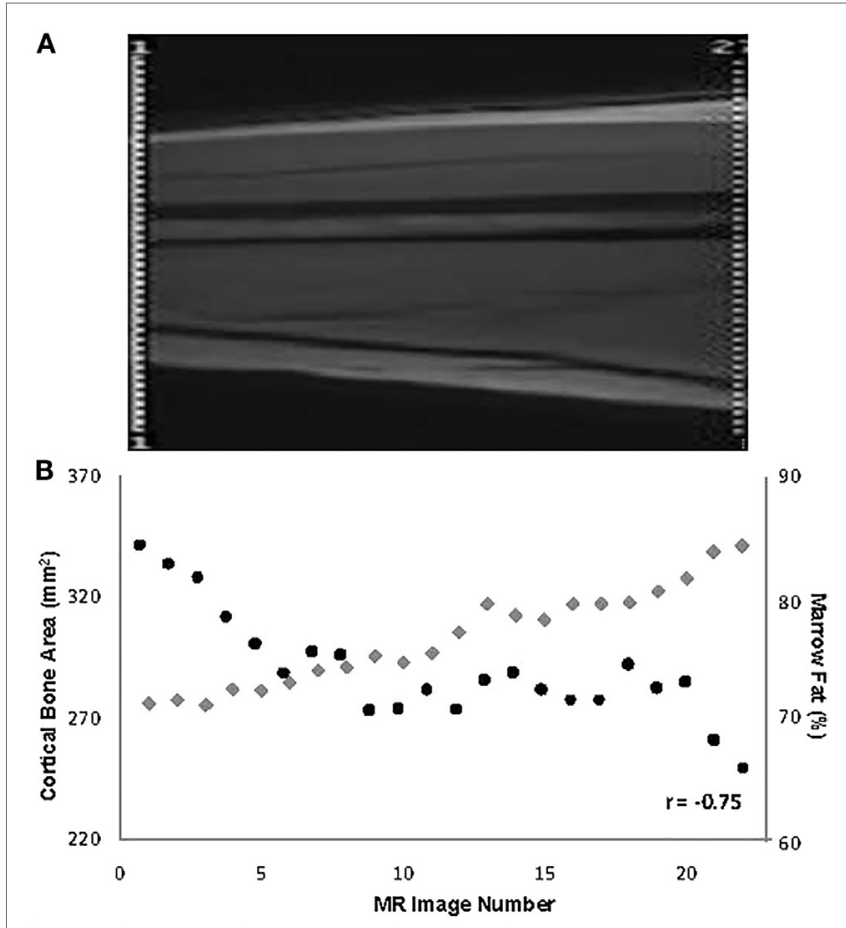

FIGURE 1 | (A) Depiction of the mid-third of the right femur in a 19-year-old male (the localizer image). (B) Values for \% marrow fat (black circles) and cortical bone area (gray diamonds) at all slices along the mid-third of the right femoral shaft and their overall relationship in the same subject [reproduced from Wren et al. (46)].

differentiation of MSCs into adipocytes is favored at the expense of osteoblasts, resulting in MF accumulation and decreased bone mass. However, this causal relationship has not yet been demonstrated.

In summary, mounting evidence supports a mechanistic relationship between MF accumulation and bone loss, pointing out the potential to target this pathway to prevent or even reverse the process of bone aging.

\section{BASIC UNDERSTANDING OF THE RELATIONSHIP BETWEEN BODY FAT, BODY WEIGHT, AND BONE STRENGTH}

In this section, we will summarize the current knowledge and conflicting data linking body fat, bone mass, and fracture rate.

\section{Clinical Observations}

Postmenopausal women have the ability to produce estrogens from the peripheral conversion of testosterone to estradiol in fat tissues. Adipocytes express the cytochrome P450 enzyme, aromatase, which can produce estradiol from testosterone. This peripheral production of estradiol has been proposed as protective mechanism against bone loss in overweight women (9-11). There are also reports showing an inverse relationship between BMI and osteoclast activity in normal postmenopausal women 
(47) and an increase in bone resorption following weight loss (48). As discussed further in the next section, fat accumulation leads to hyperinsulinemia, which is anabolic to bone, and adipocytes produce estrogen and adiponectin, which have a positive effect on bone strength and could therefore explain this positive association observed clinically (49).

Bone mineral density measured by dual-energy X-ray absorptiometry (DXA) is positively related to body weight and BMI (49, 50), possibly because higher body weight may increase mechanical loading on the skeleton, a mechanism known to stimulate bone formation. However, DXA measurements are falsely elevated by increased body fat and therefore DXA may overestimate BMD in obese individuals (51-54). Indeed, other studies have found a strong positive association between lean mass and BMD in young women and a much weaker association between BMD and fat mass (50).

A meta-analysis indicates that a high BMI appears to protect against fractures at any site in both men and women (55). Similarly, a European study found that a higher BMI protects against vertebral fractures (56). In the study of osteoporotic fractures, body weight in the lowest quartile was found to double the risk of hip fracture (57). In contrast, other studies found that the risk of hip fractures is positively correlated with fat mass in a cohort of French women (58) and Chinese men (59). Interestingly, visceral adiposity has been linked to deterioration of bone structure and skeletal fragility $(60,61)$, suggesting that fat compartments may have different effects on bone strength. In summary, clinical observations linking body fat and bone strength are inconsistent, and more mechanistic studies are needed to support the purported beneficial effect of obesity on osteoporosis.

\section{INTEGRATED HORMONAL REGULATION OF FAT AND BONE}

In this section, we will review the major hormonal regulators controlling fat and bone, with particular attention on the mechanisms underlying the reciprocal relationship between $\mathrm{MF}$ and bone.

\section{Growth Factors \\ Insulin}

Hyperinsulinemia is a hallmark of the metabolic syndrome characterized by accumulation of visceral fat (62). Osteoblasts express insulin receptors (63), and insulin directly stimulates osteoblast proliferation (64) and differentiation in vitro (63). Furthermore, local application of insulin over the calvariae of adult male mice produces a significant increase of bone formation (65). Conversely, the glucose-dependent insulinotropic polypeptide (GIP)-receptor knockout mouse shows decreased bone size, mass, and formation rate (66). In clinical studies in patients with varying degrees of hyperinsulinemia, the risk of vertebral fracture was inversely related to insulin levels (67). Hyperinsulinemia following an oral glucose load is accompanied by suppression of parathyroid hormone $(\mathrm{PTH})$ production and bone turnover and may therefore indirectly protect against bone loss $(68,69)$.

\section{Growth Hormone and Insulin-Like Growth Factor 1}

In vitro $\mathrm{GH}$ induces MSC differentiation into osteoblast, while $\mathrm{GH}$ deficiency in mice results in decreased bone formation and increased bone marrow adiposity (70). Although IGF-1 does not have a direct effect on the differentiation of MSC in vitro (71), the PPAR-gamma 2 agonist rosiglitazone decreases IGF-1 expression in bone marrow MSC and lowers blood IGF-1 levels in mice and humans (72).

\section{GLP-1 and GLP-2}

Administration of glucagon-like peptide-1 (GLP-1) to diabetic mice results in an insulin-independent anabolic effect on bone (73). In humans, dietary fat and protein leads to reduction in bone turnover (74-76) possibly through GLP glucagon-like peptide-2 (GLP-2), a polypeptide produced by intestinal L cells in response to feeding. GLP-2 administration to humans is accompanied by a reduction in bone resorption and an increase in bone density (55).

\section{Adipokines Leptin}

Leptin is primarily produced by adipocytes and initially discovered as an appetite suppressant (77). The hypothalamus is regarded as the principal target of leptin. The arcuate nucleus (in the hypothalamus) contains anabolic neurons, which express both neuropeptide $\mathrm{Y}$ and agouti-related protein, the activity of which is inhibited by leptin, and neurons expressing proopiomelanocortin (POMC), which are activated by leptin. Insulin acts on both types of neurons in the same way as leptin, suggesting that these hormones reinforce each other's actions centrally, as well as peripherally (78).

However, subsequent studies demonstrated the potent effect of leptin on bone in animal studies $(79,80)$. These studies demonstrated that in obese mice deficient in leptin (ob/ob mice) or in mice where the leptin receptor is defective ( $\mathrm{db} / \mathrm{db}$ mice), vertebral trabecular bone volume and bone formation are increased. Conversely, intracerebroventricular infusion of leptin decreased vertebral trabecular bone volume and bone formation (79). Further studies then demonstrated that these effects are mediated by the sympathetic nervous system acting on $\beta$-adrenergic receptors at the surface of osteoblasts inhibiting bone formation (80). These inhibitory effects on bone in vivo contrast with the in vitro effects reporting that leptin directly promotes the differentiation of osteoblasts (81-85). Leptin also reduces expression of RANK ligand of human bone marrow stromal cells and RANK expression of peripheral blood mononuclear cells $(81,86)$, with a resultant inhibition of osteoclastogenesis $(82,86)$. Furthermore, clinical studies have not consistently showed a relationship between administration of beta blockers, bone density improvement, and fracture prevention (87). This apparent contradiction could be explained by the ability of leptin to act positively and directly on peripheral tissues or negatively via central mechanisms involving activation of the sympathetic nervous system.

\section{Adiponectin}

Adiponectin is another adipokine produced by adipocytes whose role is to increase insulin sensitivity. Its blood levels are decreased in obese and diabetic individuals $(88,89)$. In vitro treatment of 
osteoblasts with adiponectin enhances their differentiation (90). In humans, cross-sectional studies found an inverse association between circulating adiponectin levels and bone mass in both men and women, even after adjustment for fat mass $(91,92)$.

\section{Peroxisome Proliferator-Activated Receptor (PPAR) Gamma}

PPAR $\gamma 2$ is the most important regulator of adipogenesis. In vitro PPAR $\gamma 2$ directs the commitment of MSCs into adipocytes and inhibits their differentiation into osteoblasts (9). Ablation of the PPAR $\gamma$ gene leads to enhanced osteoblastogenesis of embryonic stem cells in vitro and results in enhanced bone mass in vivo and reduced bone marrow adiposity (93). At the cellular level, ex vivo examination of MSCs shows commitment toward osteoblastogenesis and reduced adipogenesis (94). Administration of rosiglitazone, a specific activator of $\operatorname{PPAR} \gamma$, in mice decreases osteoblastogenesis and enhances adipogenesis in the bone marrow (95).

The canonical Wnt/beta-catenin pathway and non-canonical Wnt signaling have been implicated in this reciprocal regulation via PPAR-gamma 2. In the canonical pathway following ligand activation, Wnt binds to a transmembrane coreceptor complex consisting of Frizzled receptors and LRP5 to stimulate bone formation (96). Although Wnt10b, Wnt 3a, and Wnt 7 can stimulate the differentiation of MSC into osteoblast while inhibiting adipogenesis (97-101), only Wnt 7 has been shown to block PPAR-gamma 2 (99). Similarly, the non-canonical ligand Wnt5a was found to induce Runx2-mediated osteoblastogenesis while simultaneously suppressing adipogenesis in bone marrow MSC through the formation of a corepressor that blocks PPARgamma 2 gene transcription (102). In addition, PPAR-gamma 2 acts downstream of the Wnt receptor complex to enhance the proteosomic degradation of beta catenin, thereby acting as a direct regulator of osteoblastogenesis (103).

\section{Cytokines}

Duque et al. provided in vitro and in vivo evidence that interferon (IFN)-gamma is a potent inducer of MSC differentiation into mature osteoblasts and a key regulator of bone formation in mice and has therefore the potential to become an efficient drug target in osteoporosis $(104,105)$. It was further demonstrated that IFNgamma inhibits adipogenesis in vitro and prevents MF infiltration in oophorectomized mice in vivo (106). In addition, IFN-gamma suppresses osteoclast differentiation by interfering with RANKL signaling (107), thus acting synergistically on bone cells to enhance bone strength. As discussed earlier and independently of IFN-gamma, MF accumulation during aging is linked to increased expression of RANKL, highlighting another mechanism linking bone loss to MF (44). It remains to be established whether other proinflammatory and anti-inflammatory cytokines could affect the balance between MF and osteoblastogenesis.

\section{Glucocorticoids}

Excessive production or supre-physiological administration of GC excess results in inhibition of osteoblastogenesis and accelerated adipogenesis (108) through suppression of Wnt signaling (109) and induction of PPAR-gamma 2 expression (110).

\section{Calcium-Regulating Hormones Vitamin D}

Vitamin D insufficiency is a worldwide phenomenon affecting even the sunniest areas (111-113).

Vitamin D (from skin irradiation or in the diet) must be metabolically activated first by the liver 25 hydroxylase (CYP2R1) to 25hydroxyvitamin D (25OHD) and then by the kidney $1 \alpha$ hydroxylase to its active form 1,25 dihydroxyvitamin $\mathrm{D}\left[1,25(\mathrm{OH})_{2} \mathrm{D}\right]$. The role of vitamin $\mathrm{D}$ on bone and mineral homeostasis is well known, but its role in other tissue function including fat is still the subject of considerable debate.

The relationship between vitamin $\mathrm{D}$ and fat has been the subject of many studies in recent years. Several studies found a strong and inverse correlation between circulation levels of 25OHD and weight but also BMI (113-117) in both men and women across the ages. Furthermore, this inverse association was seen in all fat compartments but was stronger for visceral fat (113), perhaps indicative of higher cardiovascular morbidity. In support of this, several studies showed that decreased $25 \mathrm{OHD}$ levels impair insulin action (118-120) and are associated with the metabolic syndrome (120-122). At the cellular level, mechanistic studies also support this association. $1,25(\mathrm{OH})_{2} \mathrm{D}$ treatment of pre-adipocytes in culture decreases adipogenesis (123) through inhibition of C/EBPalpha and PPAR $\gamma ; \mathrm{VDR}$ and PPAR $\gamma$ act synergistically to inhibit adipogenesis (124). The effect of vitamin D on MF has also been examined in animal studies. Our group showed that continuous administration of $1,25(\mathrm{OH})_{2} \mathrm{D}$ in senescenceaccelerated mice (SAM-P/6) suppressed adipogenesis in the marrow and that isolated MSCs had a reduced expression of the adipogenic enhancer PPAR $\gamma$ (125) and accelerated differentiation into osteoblasts compared to placebo-treated animals. This was accompanied by an increase in both cortical and trabecular bone strength (126). Other studies also support our data that vitamin D enhances MSC differentiation to osteoblasts $(127,128)$, suggesting that $1,25(\mathrm{OH})_{2} \mathrm{D}$ may exert a protective effect on bone aging.

However, a causal relationship supporting the role of vitamin $\mathrm{D}$ as a regulator of fat metabolism and distribution in humans has been difficult to prove. In support of this theory, Ortega et al. found that baseline 25OHD levels are predictive of the efficacy of weight loss regimen and that the vitamin D status potentiates the effect of low caloric diet (129). Several other studies showed that vitamin $\mathrm{D}$ supplementation induces a moderate effect on weight loss while others did not (130-135). On the other hand, other clinical studies point to the evidence of fat as a reservoir for vitamin $\mathrm{D}$ (sequestration theory). First, it was shown that obesity is directly related to $25 \mathrm{OHD}$ levels: sequestration hypothesis $(136,137)$ and second, that weight loss tends to increase 25OHD levels (138).

An unexplored effect of vitamin $\mathrm{D}$ action on bone could come from its effect on fat accumulation in muscle. Vitamin D is also a major determinant of skeletal muscle function (139-142). A severe lack of vitamin D can cause myopathy $(143,144)$, which tends to be more marked in the proximal muscles (145). In the elderly, vitamin D deficiency is linked to muscle weakness and increased susceptibility to falls and fractures, which improve with administration of vitamin D with calcium (146-157). We recently found that in healthy young women, vitamin D levels are 
inversely related to the degree of fat infiltration in muscle (112), a phenotype associated with impaired muscle strength (19, 20, 158). Available data indicate higher muscle lipid content to also be associated with decreased muscle function in patients with neuromuscular disorders (19). Indeed, even in healthy subjects, higher muscle lipid content is associated with lower levels of muscle strength and physical performance, independent of muscle mass $(20,158)$. Among the different mechanisms that could explain the accumulation of fat in muscle, it is tempting to speculate that mesenchymal progenitors normally present in skeletal muscle - MSCs, muscle-derived stem cells, or muscle satellite cells - could potentially allow muscular growth and regeneration or differentiate into cells with an adipocyte phenotype, including the abilities to express adipocyte-specific genes and accumulate lipids (159-161).

Our studies showing that vitamin D is inversely related to fat infiltration in muscle (112) and positively related to muscle strength (139) in healthy young females support the notion that vitamin $\mathrm{D}$ may be a key determinant of muscle precursor cell (MPC) differentiation. However, whether vitamin D-mediated muscle adiposity and performance determine bone acquisition, and simultaneous decreases in marrow adiposity remains to be determined. A conceptual relationship between muscle, bone, and fat and how it could be influenced by vitamin D is shown in Figure 2.

Most vitamin D supplementation trials on muscle strength have been done in the elderly and found a reduction in falls, improvements in balance and body sway, and/or resolution of myalgia in statin-treated patients with treatment periods as short as 8-12 weeks $(146,162,163)$. Likewise, several studies have examined the impact of vitamin D supplementation on muscle composition, primarily by assessing muscle fiber number and diameter, infiltration of fat and fibrosis, and all were in elderly subjects $(152,164,165)$; treatment with vitamin D and calcium improved muscle composition after as short a time as 3 months. The ability to obtain tissue samples from healthy, young women undergoing surgery for sports-related injuries represents a unique approach in this field of research.

Two vitamin D supplementation studies have been done in girls; one found improvements in muscle function in the vitamin D-treated group but no significant differences in bone measures using DXA and peripheral quantitative computed tomography (CT), while the other found increases in DXA

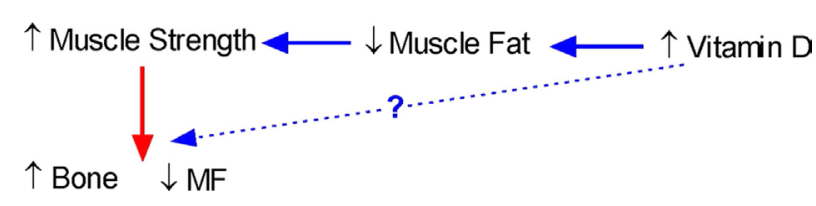

FIGURE 2 | Conceptual model of the interrelationship between bone, fat, and muscle and the role of vitamin $\mathbf{D}$. An increase in vitamin $D$ should lead to a decrease in muscle fat leading to an increase in muscle strength and a subsequent increase in bone and simultaneous decrease in marrow fat (MF). However, there is also the possibility that increases in vitamin D will also directly lead to an increase in bone. measures of lean mass and spine bone mineral content (139, 166). These discrepant results likely reflect the limitations of the techniques employed. Changes in body composition influence DXA measures during growth, and peripheral quantitative CT measures in children have poor reproducibility due to large variations in bone growth $(167,168)$. Confounding effects associated with growth and development are common when studying sexually and skeletally immature young women, using DXA or CT.

\section{Parathyroid Hormone}

Parathyroid hormone is a major regulator of calcium and bone homeostasis, but studies on its effect of fat have been so far limited. Two epidemiological studies suggest a possible positive association between circulating levels of PTH and fat mass. The first showed that circulating PTH concentrations are directly correlated with fat mass (169), and the other showed that body weight is increased in women with primary hyperparathyroidism as compared to controls (170).

\section{BROWN ADIPOSE TISSUE AND BONE}

Much of this review focused on the interaction between white fat and bone, which is by far the most studied. In contrast, the literature on BAT and bone is almost non-existent except for two correlative studies showing that a positive relationship exists between BAT and bone volume in children and adolescent boys and girls (171), and BAT and bone size in both children and adults $(171,172)$. The effect of BAT became insignificant when muscle mass was introduced in the model, a finding supported by a previous study showing a positive relationship between BAT and muscle mass (173). It has also been reported that young women with active BAT have higher BMD than women without BAT (174), further supporting a possible mechanistic relationship between BAT, bone growth, and bone strength. The underlying mechanism(s) remains to be established.

\section{THE CHALLENGES OF FAT IMAGING}

In this section, we will briefly summarize the recent progress in non-invasive measurement of MF and body using imaging technologies.

Studies assessing MF-bone interactions have been hindered by the difficulty of independently examining different tissues at the same site. The most commonly employed method to assess bone and body composition has been DXA, which cannot analyze muscle or MF. In contrast, CT and MRI provide accurate measures of bone, muscle, and fat independently (175-179). MRI has the added advantage of being able to quantify the amount of any tissue without exposing the subject to radiation. However, MRI measurements of bone, bone-MF, and muscle require state-of-the-art imaging, including Dixon capabilities. Over the past 25 years, Dixon's method has evolved significantly $(19,177,180-183)$, and recent advances have led to more generalized algorithms (176, 184-186). We used three-point Dixon MR technique for fat quantification (182) and determined that reproducibility of the fat fraction quantifications in phantom models was excellent with 
a coefficient of variation of $<1.5 \%$ (182). In vivo reproducibility of MF varies between 1.3 and 3\% $(176,177)$. Pixel signal intensities from the medullary canal are obtained, and total fat $\%$ is calculated by integration in slice selection direction over the imaging volume. To calculate bone structural properties from the MRI images, our group has developed a graphical user interface with Matlab (Mathworks, Natick, MA, USA) using custom algorithms. The program is designed to automatically extract endosteal and periosteal contours of the bone and to calculate geometric and structural parameters. First, the user selects a DICOM image and then crops a rectangular region of interest containing the bone of interest. The image is automatically thresholded according to bone and muscle peaks from the image histogram. Edges of the cortex are detected and contours generated. The correlation of this method with quantitative CT is excellent (187). Multiple investigators have previously evaluated properties of the femoral midshaft using tracing (188), deformable models (189), and semi-automatic algorithms.

Possible differences in the distribution of fat accumulation in children have been difficult to establish due to the limitations and the risks of the techniques used. While there are many techniques, including underwater weighing, anthropometry, body water dilution, impedance, and DXA, to estimate total body fat content, it has not been possible to differentiate between subcutaneous and visceral fat until the advent of CT and MRI (190). Both CT and MRI provide a three-dimensional assessment of body tissues (175). CT provides cross-sectional images from which the amounts and distributions of subcutaneous fat and visceral fat are well distinguished, but these determinations are areal measurements $\left(\mathrm{cm}^{2}\right)$ and multiple scans are necessary to obtain true volumetric values, exposing the child to radiation. In contrast, MRI allows for volume determinations and can reliably measure the amount and distribution of abdominal fat, without radiation

\section{REFERENCES}

1. Osteoporosis prevention, diagnosis, and therapy. NIH Consens Statement (2000) 17(1):1-45.

2. Kanis JA, McCloskey EV, Johansson H, Strom O, Borgstrom F, Oden A. Case finding for the management of osteoporosis with FRAX - assessment and intervention thresholds for the UK. Osteoporos Int (2008) 19(10):1395-408. doi:10.1007/s00198-008-0712-1

3. Recker RR, Heaney RP. Peak bone mineral density in young women. JAMA (1993) 270(24):2926-7. doi:10.1001/jama.1993.03510240038018

4. Hoiberg M, Nielsen TL, Wraae K, Abrahamsen B, Hagen C, Andersen $\mathrm{M}$, et al. Population-based reference values for bone mineral density in young men. Osteoporos Int (2007) 18(11):1507-14. doi:10.1007/ s00198-007-0399-8

5. Rosen CJ, Beamer WG, Donahue LR. Defining the genetics of osteoporosis: using the mouse to understand man. Osteoporos Int (2001) 12(10):803-10. doi:10.1007/s001980170030

6. Brown SA, Rosen CJ. Osteoporosis. Med Clin North Am (2003) 87(5):1039-63. doi:10.1016/S0025-7125(03)00065-8

7. Kveiborg M, Flyvbjerg A, Rattan SI, Kassem M. Changes in the insulin-like growth factor-system may contribute to in vitro age-related impaired osteoblast functions. Exp Gerontol (2000) 35(8):1061-74. doi:10.1016/ S0531-5565(00)00125-X

8. Fedarko NS, Vetter UK, Weinstein S, Robey PG. Age-related changes in hyaluronan, proteoglycan, collagen, and osteonectin synthesis by human bone cells. J Cell Physiol (1992) 151(2):215-27. doi:10.1002/ jcp. 1041510202 exposure $\left(\mathrm{cm}^{3}\right)(175,179)$. In a study comparing MRI with five other methods (underwater weighing, $\mathrm{O}$ dilution, $\mathrm{K}$ counting, skinfold thickness, and body electrical impedance methods), MR gave the least variability and an estimate of body fat significantly closer to the mean of the five other methods than any other technique alone. MRI-based studies are likely to be less affected by individual variability and may therefore achieve higher statistical power for a given sample size (178).

\section{CONCLUSION}

The interactions between fat and bone are complex and new emerging concepts regarding their relationship have the potential of transforming our therapeutic targeting of the skeleton. The inverse relationship between MF and bone is an enthralling area of research based on the very origin of bone and fat cell differentiation from MSC. The obesity epidemic has also brought new challenges in terms of prevention and treatment of common illnesses, such as type 2 diabetes. Here again, the interactions between body weight, body fat, and bone are much more complex, and the influence of clinical context, age, sex, and ethnicity should be considered when examining this relationship. Overall, bone and fat may not be such an odd couple but rather a very important one that deserves to be examined in all its facets as it represents a unique challenge for future health.

\section{ACKNOWLEDGMENTS}

This work was supported by National Institutes of Health Grant 1R01 AR052744-01, Department of the Army Grant DAMD1701-1-0817, and Canadian Institutes of Health Research Grant MT-10839, Department of Defense Grant BCRP 142405.

9. Aubin JE. Bone stem cells. J Cell Biochem Suppl (1998) 30-31:73-82. doi:10.1002/(SICI)1097-4644(1998)72:30/31+<73::AID-JCB11>3.0.CO;2-L

10. Cohen PG. Aromatase, adiposity, aging and disease. The hypogonadalmetabolic-atherogenic-disease and aging connection. Med Hypotheses (2001) 56(6):702-8. doi:10.1054/mehy.2000.1169

11. Gimble JM, Robinson CE, Wu X, Kelly KA. The function of adipocytes in the bone marrow stroma: an update. Bone (1996) 19(5):421-8. doi:10.1016/ S8756-3282(96)00258-X

12. Dempster DW. Osteoporosis and the burden of osteoporosis-related fractures. Am J Manag Care (2011) 17(Suppl 6):S164-9.

13. Datta HK, Ng WF, Walker JA, Tuck SP, Varanasi SS. The cell biology of bone metabolism. J Clin Pathol (2008) 61(5):577-87. doi:10.1136/jcp.2007.048868

14. Manolagas SC. Birth and death of bone cells: basic regulatory mechanisms and implications for the pathogenesis and treatment of osteoporosis. Endocr $\operatorname{Rev}(2000)$ 21(2):115-37. doi:10.1210/er.21.2.115

15. Horowitz MC, Lorenzo JA. The origins of osteoclasts. Curr Opin Rheumatol (2004) 16(4):464-8. doi:10.1097/01.bor.0000127825.05580.eb

16. Di Iorgi N, Mo AO, Grimm K, Wren TA, Dorey F, Gilsanz V. Bone acquisition in healthy young females is reciprocally related to marrow adiposity. J Clin Endocrinol Metab (2010) 95(6):2977-82. doi:10.1210/jc.2009-2336

17. Himms-Hagen J. Brown adipose tissue thermogenesis: interdisciplinary studies. FASEB J (1990) 4(11):2890-8.

18. Nedergaard J, Bengtsson T, Cannon B. Unexpected evidence for active brown adipose tissue in adult humans. Am J Physiol Endocrinol Metab (2007) 293(2):E444-52. doi:10.1152/ajpendo.00691.2006

19. Wren TA, Bluml S, Tseng-Ong L, Gilsanz V. Three-point technique of fat quantification of muscle tissue as a marker of disease progression in 
Duchenne muscular dystrophy: preliminary study. AJR Am J Roentgenol (2008) 190(1):W8-12. doi:10.2214/AJR.07.2732

20. Visser M, Goodpaster BH, Kritchevsky SB, Newman AB, Nevitt M, Rubin $\mathrm{SM}$, et al. Muscle mass, muscle strength, and muscle fat infiltration as predictors of incident mobility limitations in well-functioning older persons. J Gerontol A Biol Sci Med Sci (2005) 60(3):324-33. doi:10.1093/ gerona/60.3.324

21. Lang T, Cauley JA, Tylavsky F, Bauer D, Cummings S, Harris TB. Computed tomographic measurements of thigh muscle cross-sectional area and attenuation coefficient predict hip fracture: the health, aging, and body composition study. J Bone Miner Res (2010) 25(3):513-9. doi:10.1359/jbmr.090807

22. Meunier P, Aaron J, Edouard C, Vignon G. Osteoporosis and the replacement of cell populations of the marrow by adipose tissue. A quantitative study of 84 iliac bone biopsies. Clin Orthop Relat Res (1971) 80:147-54. doi:10.1097/00003086-197110000-00021

23. Justesen J, Stenderup K, Ebbesen EN, Mosekilde L, Steiniche T, Kassem M. Adipocyte tissue volume in bone marrow is increased with aging and in patients with osteoporosis. Biogerontology (2001) 2(3):165-71. doi:10.10 23/A:1011513223894

24. Rozman C, Feliu E, Berga L, Reverter JC, Climent C, Ferran MJ. Age-related variations of fat tissue fraction in normal human bone marrow depend both on size and number of adipocytes: a stereological study. Exp Hematol (1989) 17(1):34-7.

25. Verma S, Rajaratnam JH, Denton J, Hoyland JA, Byers RJ. Adipocytic proportion of bone marrow is inversely related to bone formation in osteoporosis. $J$ Clin Pathol (2002) 55(9):693-8. doi:10.1136/jcp.55.9.693

26. Wehrli FW, Hopkins JA, Hwang SN, Song HK, Snyder PJ, Haddad JG. Cross-sectional study of osteopenia with quantitative MR imaging and bone densitometry. Radiology (2000) 217(2):527-38. doi:10.1148/ radiology.217.2.r00nv20527

27. Cui Q, Wang GJ, Balian G. Pluripotential marrow cells produce adipocytes when transplanted into steroid-treated mice. Connect Tissue Res (2000) 41(1):45-56. doi:10.3109/03008200009005641

28. Li X, Jin L, Cui Q, Wang GJ, Balian G. Steroid effects on osteogenesis through mesenchymal cell gene expression. Osteoporos Int (2005) 16(1):101-8. doi:10.1007/s00198-004-1649-7

29. van Staa TP, Leufkens HG, Cooper C. The epidemiology of corticosteroidinduced osteoporosis: a meta-analysis. Osteoporos Int (2002) 13(10):777-87. doi:10.1007/s001980200108

30. Rodriguez JP, Montecinos L, Rios S, Reyes P, Martinez J. Mesenchymal stem cells from osteoporotic patients produce a type I collagen-deficient extracellular matrix favoring adipogenic differentiation. J Cell Biochem (2000) 79(4):557-65. doi:10.1002/1097-4644(20001215)79:4<557::AID-JCB40>3.0.CO;2-H

31. Sekiya I, Larson BL, Vuoristo JT, Cui JG, Prockop DJ. Adipogenic differentiation of human adult stem cells from bone marrow stroma (MSCs). J Bone Miner Res (2004) 19(2):256-64. doi:10.1359/JBMR.0301220

32. Weisberg SP, McCann D, Desai M, Rosenbaum M, Leibel RL, Ferrante AW Jr. Obesity is associated with macrophage accumulation in adipose tissue. J Clin Invest (2003) 112(12):1796-808. doi:10.1172/JCI200319246

33. Jiang Y, Jahagirdar BN, Reinhardt RL, Schwartz RE, Keene CD, OrtizGonzalez XR, et al. Pluripotency of mesenchymal stem cells derived from adult marrow. Nature (2002) 418(6893):41-9. doi:10.1038/nature00870

34. Cowin SC, Weinbaum S, Zeng Y. A case for bone canaliculi as the anatomical site of strain generated potentials. J Biomech (1995) 28(11):1281-97. doi:10.1016/0021-9290(95)00058-P

35. Gilsanz V, Wren TA, Sanchez M, Dorey F, Judex S, Rubin C. Low-level, high-frequency mechanical signals enhance musculoskeletal development of young women with low BMD. J Bone Miner Res (2006) 21(9):1464-74. doi:10.1359/jbmr.060612

36. Kontulainen S, Sievanen H, Kannus P, Pasanen M, Vuori I. Effect of longterm impact-loading on mass, size, and estimated strength of humerus and radius of female racquet-sports players: a peripheral quantitative computed tomography study between young and old starters and controls. J Bone Miner Res (2003) 18(2):352-9. doi:10.1359/jbmr.2003.18.2.352

37. MacKelvie KJ, Khan KM, Petit MA, Janssen PA, McKay HA. A schoolbased exercise intervention elicits substantial bone health benefits: a 2-year randomized controlled trial in girls. Pediatrics (2003) 112(6 Pt 1):e447. doi:10.1542/peds.112.6.e447
38. Swan CC, Lakes RS, Brand RA, Stewart KJ. Micromechanically based poroelastic modeling of fluid flow in Haversian bone. J Biomech Eng (2003) 125(1):25-37. doi:10.1115/1.1535191

39. Weinbaum S, Cowin SC, Zeng Y. A model for the excitation of osteocytes by mechanical loading-induced bone fluid shear stresses. J Biomech (1994) 27(3):339-60. doi:10.1016/0021-9290(94)90010-8

40. Martin RB, Zissimos SL. Relationships between marrow fat and bone turnover in ovariectomized and intact rats. Bone (1991) 12(2):123-31. doi:10.1016/8756-3282(91)90011-7

41. Griffith JF, Yeung DK, Antonio GE, Lee FK, Hong AW, Wong SY, et al. Vertebral bone mineral density, marrow perfusion, and fat content in healthy men and men with osteoporosis: dynamic contrast-enhanced MR imaging and MR spectroscopy. Radiology (2005) 236(3):945-51. doi:10.1148/ radiol.2363041425

42. Hartsock RJ, Smith EB, Petty CS. Normal variations with aging of the amount of hematopoietic tissue in bone marrow from the anterior iliac crest. A study made from 177 cases of sudden death examined by necropsy. Am JClin Pathol (1965) 43:326-31.

43. Schellinger D, Lin CS, Hatipoglu HG, Fertikh D. Potential value of vertebral proton MR spectroscopy in determining bone weakness. AJNR Am J Neuroradiol (2001) 22(8):1620-7.

44. Takeshita S, Fumoto T, Naoe Y, Ikeda K. Age-related marrow adipogenesis is linked to increased expression of RANKL. J Biol Chem (2014) 289(24):16699-710. doi:10.1074/jbc.M114.547919

45. Di Iorgi N, Rosol M, Mittelman SD, Gilsanz V. Reciprocal relation between marrow adiposity and the amount of bone in the axial and appendicular skeleton of young adults. J Clin Endocrinol Metab (2008) 93(6):2281-6. doi:10.1210/jc.2007-2691

46. Wren TA, Chung SA, Dorey FJ, Bluml S, Adams GB, Gilsanz V. Bone marrow fat is inversely related to cortical bone in young and old subjects. J Clin Endocrinol Metab (2011) 96(3):782-6. doi:10.1210/jc.2010-1922

47. Revilla M, Villa LF, Sanchez-Atrio A, Hernandez ER, Rico H. Influence of body mass index on the age-related slope of total and regional bone mineral content. Calcif Tissue Int (1997) 61(2):134-8. doi:10.1007/s002239900310

48. Ricci TA, Heymsfield SB, Pierson RN Jr, Stahl T, Chowdhury HA, Shapses SA. Moderate energy restriction increases bone resorption in obese postmenopausal women. Am J Clin Nutr (2001) 73(2):347-52.

49. Reid IR. Relationships among body mass, its components, and bone. Bone (2002) 31(5):547-55. doi:10.1016/S8756-3282(02)00864-5

50. Wang MC, Bachrach LK, Van Loan M, Hudes M, Flegal KM, Crawford PB. The relative contributions of lean tissue mass and fat mass to bone density in young women. Bone (2005) 37(4):474-81. doi:10.1016/j.bone.2005.04.038

51. Grampp S, Genant HK, Mathur A, Lang P, Jergas M, Takada M, et al. Comparisons of noninvasive bone mineral measurements in assessing age-related loss, fracture discrimination, and diagnostic classification. J Bone Miner Res (1997) 12(5):697-711. doi:10.1359/jbmr.1997.12.5.697

52. Guglielmi G, Grimston SK, Fischer KC, Pacifici R. Osteoporosis: diagnosis with lateral and posteroanterior dual X-ray absorptiometry compared with quantitative CT. Radiology (1994) 192(3):845-50. doi:10.1148/ radiology.192.3.8058958

53. Javed F, Yu W, Thornton J, Colt E. Effect of fat on measurement of bone mineral density. Int J Body Compos Res (2009) 7(1):37-40.

54. JM W, CE C. Dual energy X-ray absorptiometry (DXA) in obese patient: are normal values really normal? J Women's Imaging (1999) 1:11.

55. De Laet C, Kanis JA, Oden A, Johanson H, Johnell O, Delmas P, et al. Body mass index as a predictor of fracture risk: a meta-analysis. Osteoporos Int (2005) 16(11):1330-8. doi:10.1007/s00198-005-1863-y

56. Johnell O, O’Neill T, Felsenberg D, Kanis J, Cooper C, Silman AJ. Anthropometric measurements and vertebral deformities. European Vertebral Osteoporosis Study (EVOS) Group. Am J Epidemiol (1997) 146(4):287-93. doi:10.1093/oxfordjournals.aje.a009269

57. Ensrud KE, Lipschutz RC, Cauley JA, Seeley D, Nevitt MC, Scott J, et al. Body size and hip fracture risk in older women: a prospective study. Study of Osteoporotic Fractures Research Group. Am J Med (1997) 103(4):274-80. doi:10.1016/S0002-9343(97)00025-9

58. Schott AM, Cormier C, Hans D, Favier F, Hausherr E, Dargent-Molina P, et al. How hip and whole-body bone mineral density predict hip fracture in elderly women: the EPIDOS Prospective Study. Osteoporos Int (1998) 8(3):247-54. doi:10.1007/s001980050061 
59. Lau EM, Chan YH, Chan M, Woo J, Griffith J, Chan HH, et al. Vertebral deformity in Chinese men: prevalence, risk factors, bone mineral density, and body composition measurements. Calcif Tissue Int (2000) 66(1):47-52. doi: $10.1007 / \mathrm{s} 002230050009$

60. Gilsanz V, Chalfant J, Mo AO, Lee DC, Dorey FJ, Mittelman SD. Reciprocal relations of subcutaneous and visceral fat to bone structure and strength. $J$ Clin Endocrinol Metab (2009) 94(9):3387-93. doi:10.1210/jc.2008-2422

61. Goulding A, Jones IE, Taylor RW, Williams SM, Manning PJ. Bone mineral density and body composition in boys with distal forearm fractures: a dual-energy X-ray absorptiometry study. J Pediatr (2001) 139(4):509-15. doi:10.1067/mpd.2001.116297

62. Bergman RN, Kim SP, Catalano KJ, Hsu IR, Chiu JD, Kabir M, et al. Why visceral fat is bad: mechanisms of the metabolic syndrome. Obesity (2006) 14(Suppl 1):16s-9s. doi:10.1038/oby.2006.277

63. Levy JR, Murray E, Manolagas S, Olefsky JM. Demonstration of insulin receptors and modulation of alkaline phosphatase activity by insulin in rat osteoblastic cells. Endocrinology (1986) 119(4):1786-92. doi:10.1210/ endo-119-4-1786

64. Hickman J, McElduff A. Insulin promotes growth of the cultured rat osteosarcoma cell line UMR-106-01: an osteoblast-like cell. Endocrinology (1989) 124(2):701-6. doi:10.1210/endo-124-2-701

65. Cornish J, Callon KE, Reid IR. Insulin increases histomorphometric indices of bone formation in vivo. Calcif Tissue Int (1996) 59(6):492-5. doi:10.1007/ BF00369216

66. Xie D, Cheng H, Hamrick M, Zhong Q, Ding KH, Correa D, et al. Glucosedependent insulinotropic polypeptide receptor knockout mice have altered bone turnover. Bone (2005) 37(6):759-69. doi:10.1016/j.bone.2005.06.021

67. Ahmed LA, Schirmer H, Berntsen GK, Fonnebo V, Joakimsen RM. Features of the metabolic syndrome and the risk of non-vertebral fractures: the Troms $\emptyset$ study. Osteoporos Int (2006) 17(3):426-32. doi:10.1007/s00198-005-0003-z

68. Clowes JA, Robinson RT, Heller SR, Eastell R, Blumsohn A. Acute changes of bone turnover and PTH induced by insulin and glucose: euglycemic and hypoglycemic hyperinsulinemic clamp studies. J Clin Endocrinol Metab (2002) 87(7):3324-9. doi:10.1210/jcem.87.7.8660

69. D’Erasmo E, Pisani D, Ragno A, Raejntroph N, Vecci E, Acca M. Calcium homeostasis during oral glucose load in healthy women. Horm Metab Res (1999) 31(4):271-3. doi:10.1055/s-2007-978731

70. Gevers EF, Loveridge N, Robinson IC. Bone marrow adipocytes: a neglected target tissue for growth hormone. Endocrinology (2002) 143(10):4065-73. doi:10.1210/en.2002-220428

71. Thomas T, Gori F, Spelsberg TC, Khosla S, Riggs BL, Conover CA. Response of bipotential human marrow stromal cells to insulin-like growth factors: effect on binding protein production, proliferation, and commitment to osteoblasts and adipocytes. Endocrinology (1999) 140(11):5036-44. doi:10.1210/endo.140.11.7128

72. Lecka-Czernik B, Ackert-Bicknell C, Adamo ML, Marmolejos V, Churchill GA, Shockley KR, et al. Activation of peroxisome proliferator-activated receptor gamma (PPARgamma) by rosiglitazone suppresses components of the insulin-like growth factor regulatory system in vitro and in vivo. Endocrinology (2007) 148(2):903-11. doi:10.1210/en.2006-1121

73. Nuche-Berenguer B, Moreno P, Esbrit P, Dapia S, Caeiro JR, Cancelas J, et al. Effect of GLP-1 treatment on bone turnover in normal, type 2 diabetic, and insulin-resistant states. Calcif Tissue Int (2009) 84(6):453-61. doi:10.1007/ s00223-009-9220-3

74. Bjarnason NH, Henriksen EE, Alexandersen P, Christgau S, Henriksen DB, Christiansen C. Mechanism of circadian variation in bone resorption. Bone (2002) 30(1):307-13. doi:10.1016/S8756-3282(01)00662-7

75. Clowes JA, Hannon RA, Yap TS, Hoyle NR, Blumsohn A, Eastell R. Effect of feeding on bone turnover markers and its impact on biological variability of measurements. Bone (2002) 30(6):886-90. doi:10.1016/ S8756-3282(02)00728-7

76. Henriksen DB, Alexandersen P, Bjarnason NH, Vilsboll T, Hartmann B, Henriksen EE, et al. Role of gastrointestinal hormones in postprandial reduction of bone resorption. J Bone Miner Res (2003) 18(12):2180-9. doi:10.1359/ jbmr.2003.18.12.2180

77. Brennan AM, Mantzoros CS. Drug insight: the role of leptin in human physiology and pathophysiology - emerging clinical applications. Nat Clin Pract Endocrinol Metab (2006) 2(6):318-27. doi:10.1038/ncpendmet0196
78. Barsh GS, Schwartz MW. Genetic approaches to studying energy balance: perception and integration. Nat Rev Genet (2002) 3(8):589-600.

79. Ducy P, Amling M, Takeda S, Priemel M, Schilling AF, Beil FT, et al. Leptin inhibits bone formation through a hypothalamic relay: a central control of bone mass. Cell (2000) 100(2):197-207. doi:10.1016/ S0092-8674(00)81558-5

80. Takeda S, Elefteriou F, Levasseur R, Liu X, Zhao L, Parker KL, et al. Leptin regulates bone formation via the sympathetic nervous system. Cell (2002) 111(3):305-17. doi:10.1016/S0092-8674(02)01049-8

81. Burguera B, Hofbauer LC, Thomas T, Gori F, Evans GL, Khosla S, et al. Leptin reduces ovariectomy-induced bone loss in rats. Endocrinology (2001) 142(8):3546-53. doi:10.1210/endo.142.8.8346

82. Cornish J, Callon KE, Bava U, Lin C, Naot D, Hill BL, et al. Leptin directly regulates bone cell function in vitro and reduces bone fragility in vivo. J Endocrinol (2002) 175(2):405-15. doi:10.1677/joe.0.1750405

83. Elefteriou F, Ahn JD, Takeda S, Starbuck M, Yang X, Liu X, et al. Leptin regulation of bone resorption by the sympathetic nervous system and CART. Nature (2005) 434(7032):514-20. doi:10.1038/nature03398

84. Gordeladze JO, Drevon CA, Syversen U, Reseland JE. Leptin stimulates human osteoblastic cell proliferation, de novo collagen synthesis, and mineralization: impact on differentiation markers, apoptosis, and osteoclastic signaling. J Cell Biochem (2002) 85(4):825-36. doi:10.1002/jcb.10156

85. Thomas T, Gori F, Khosla S, Jensen MD, Burguera B, Riggs BL. Leptin acts on human marrow stromal cells to enhance differentiation to osteoblasts and to inhibit differentiation to adipocytes. Endocrinology (1999) 140(4):1630-8. doi:10.1210/en.140.4.1630

86. Holloway WR, Collier FM, Aitken CJ, Myers DE, Hodge JM, Malakellis M, et al. Leptin inhibits osteoclast generation. J Bone Miner Res (2002) 17(2):200-9. doi:10.1359/jbmr.2002.17.2.200

87. Reid IR, Gamble GD, Grey AB, Black DM, Ensrud KE, Browner WS, et al. beta-Blocker use, BMD, and fractures in the study of osteoporotic fractures. J Bone Miner Res (2005) 20(4):613-8. doi:10.1359/JBMR.041202

88. Berg AH, Combs TP, Du X, Brownlee M, Scherer PE. The adipocyte-secreted protein Acrp30 enhances hepatic insulin action. Nat Med (2001) 7(8):947-53. doi:10.1038/90992

89. Weyer C, Funahashi T, Tanaka S, Hotta K, Matsuzawa Y, Pratley RE, et al. Hypoadiponectinemia in obesity and type 2 diabetes: close association with insulin resistance and hyperinsulinemia. J Clin Endocrinol Metab (2001) 86(5):1930-5. doi:10.1210/jcem.86.5.7463

90. Berner HS, Lyngstadaas SP, Spahr A, Monjo M, Thommesen L, Drevon CA, et al. Adiponectin and its receptors are expressed in bone-forming cells. Bone (2004) 35(4):842-9. doi:10.1016/j.bone.2004.06.008

91. Lenchik L, Register TC, Hsu FC, Lohman K, Nicklas BJ, Freedman BI, et al. Adiponectin as a novel determinant of bone mineral density and visceral fat. Bone (2003) 33(4):646-51. doi:10.1016/S8756-3282(03)00237-0

92. Richards JB, Valdes AM, Burling K, Perks UC, Spector TD. Serum adiponectin and bone mineral density in women. J Clin Endocrinol Metab (2007) 92(4):1517-23. doi:10.1210/jc.2006-2097

93. Akune T, Ohba S, Kamekura S, Yamaguchi M, Chung UI, Kubota N, et al. PPARgamma insufficiency enhances osteogenesis through osteoblast formation from bone marrow progenitors. J Clin Invest (2004) 113(6):846-55. doi:10.1172/JCI200419900

94. Kawaguchi H, Akune T, Yamaguchi M, Ohba S, Ogata N, Chung UI, et al. Distinct effects of PPARgamma insufficiency on bone marrow cells, osteoblasts, and osteoclastic cells. J Bone Miner Metab (2005) 23(4):275-9. doi:10.1007/s00774-005-0599-2

95. Rzonca SO, Suva LJ, Gaddy D, Montague DC, Lecka-Czernik B. Bone is a target for the antidiabetic compound rosiglitazone. Endocrinology (2004) 145(1):401-6. doi:10.1210/en.2003-0746

96. Piters E, Boudin E, Van Hul W. Wnt signaling: a win for bone. Arch Biochem Biophys (2008) 473(2):112-6. doi:10.1016/j.abb.2008.03.006

97. Bennett CN, Longo KA, Wright WS, Suva LJ, Lane TF, Hankenson KD, et al. Regulation of osteoblastogenesis and bone mass by Wnt10b. Proc Natl Acad Sci U S A (2005) 102(9):3324-9. doi:10.1073/pnas.0408742102

98. Cheng SL, Shao JS, Charlton-Kachigian N, Loewy AP, Towler DA. MSX2 promotes osteogenesis and suppresses adipogenic differentiation of multipotent mesenchymal progenitors. J Biol Chem (2003) 278(46):45969-77. doi:10.1074/jbc.M306972200 
99. Ichida F, Nishimura R, Hata K, Matsubara T, Ikeda F, Hisada K, et al. Reciprocal roles of MSX2 in regulation of osteoblast and adipocyte differentiation. J Biol Chem (2004) 279(32):34015-22. doi:10.1074/jbc.M403621200

100. Jackson A, Vayssiere B, Garcia T, Newell W, Baron R, Roman-Roman S, et al. Gene array analysis of Wnt-regulated genes in C3H10T1/2 cells. Bone (2005) 36(4):585-98. doi:10.1016/j.bone.2005.01.007

101. Sadie-Van Gijsen H, Smith W, du Toit EF, Michie J, Hough FS, Ferris WF. Depot-specific and hypercaloric diet-induced effects on the osteoblast and adipocyte differentiation potential of adipose-derived stromal cells. Mol Cell Endocrinol (2012) 348(1):55-66. doi:10.1016/j.mce.2011.07.030

102. Takada I, Mihara M, Suzawa M, Ohtake F, Kobayashi S, Igarashi M, et al. A histone lysine methyltransferase activated by non-canonical Wnt signalling suppresses PPAR-gamma transactivation. Nat Cell Biol (2007) 9(11):1273-85. doi:10.1038/ncb1647

103. Moldes M, Zuo Y, Morrison RF, Silva D, Park BH, Liu J, et al. Peroxisomeproliferator-activated receptor gamma suppresses Wnt/beta-catenin signalling during adipogenesis. Biochem J (2003) 376(Pt 3):607-13. doi:10.1042/ bj20030426

104. Duque G, Huang DC, Dion N, Macoritto M, Rivas D, Li W, et al. Interferongamma plays a role in bone formation in vivo and rescues osteoporosis in ovariectomized mice. J Bone Miner Res (2011) 26(7):1472-83. doi:10.1002/ jbmr.350

105. Duque G, Huang DC, Macoritto M, Rivas D, Yang XF, Ste-Marie LG, et al. Autocrine regulation of interferon gamma in mesenchymal stem cells plays a role in early osteoblastogenesis. Stem Cells (2009) 27(3):550-8. doi:10.1634/ stemcells.2008-0886

106. Vidal C, Bermeo S, Li W, Huang D, Kremer R, Duque G. Interferon gamma inhibits adipogenesis in vitro and prevents marrow fat infiltration in oophorectomized mice. Stem Cells (2012) 30(5):1042-8. doi:10.1002/stem.1063

107. Takayanagi H, Ogasawara K, Hida S, Chiba T, Murata S, Sato K, et al. T-cell-mediated regulation of osteoclastogenesis by signalling cross-talk between RANKL and IFN-gamma. Nature (2000) 408(6812):600-5. doi:10.1038/35046102

108. Fernandez-Rodriguez E, Stewart PM, Cooper MS. The pituitary-adrenal axis and body composition. Pituitary (2009) 12(2):105-15. doi:10.1007/ s11102-008-0098-2

109. Ohnaka K, Tanabe M, Kawate H, Nawata H, Takayanagi R. Glucocorticoid suppresses the canonical Wnt signal in cultured human osteoblasts. Biochem Biophys Res Commun (2005) 329(1):177-81. doi:10.1016/j.bbrc.2005.01.117

110. Pereira RC, Delany AM, Canalis E. Effects of cortisol and bone morphogenetic protein-2 on stromal cell differentiation: correlation with CCAAT-enhancer binding protein expression. Bone (2002) 30(5):685-91. doi:10.1016/ S8756-3282(02)00687-7

111. Holick MF. Vitamin D deficiency. N Engl J Med (2007) 357(3):266-81. doi:10.1056/NEJMra070553

112. Gilsanz V, Kremer A, Mo AO, Wren TA, Kremer R. Vitamin D status and its relation to muscle mass and muscle fat in young women. J Clin Endocrinol Metab (2010) 95(4):1595-601. doi:10.1210/jc.2009-2309

113. Kremer R, Campbell PP, Reinhardt T, Gilsanz V. Vitamin D status and its relationship to body fat, final height, and peak bone mass in young women. $J$ Clin Endocrinol Metab (2009) 94(1):67-73. doi:10.1210/jc.2008-1575

114. Arunabh S, Pollack S, Yeh J, Aloia JF. Body fat content and 25-hydroxyvitamin D levels in healthy women. J Clin Endocrinol Metab (2003) 88(1):157-61. doi:10.1210/jc.2002-020978

115. Buffington C, Walker B, Cowan GS Jr, Scruggs D. Vitamin D deficiency in the morbidly obese. Obes Surg (1993) 3(4):421-4. doi:10.1381/096089293765559142

116. Kamycheva E, Joakimsen RM, Jorde R. Intakes of calcium and vitamin D predict body mass index in the population of Northern Norway. J Nutr (2003) 133(1):102-6.

117. Parikh SJ, Edelman M, Uwaifo GI, Freedman RJ, Semega-Janneh M, Reynolds J, et al. The relationship between obesity and serum 1,25-dihydroxy vitamin D concentrations in healthy adults. J Clin Endocrinol Metab (2004) 89(3):1196-9. doi:10.1210/jc.2003-031398

118. Borissova AM, Tankova T, Kirilov G, Dakovska L, Kovacheva R. The effect of vitamin D3 on insulin secretion and peripheral insulin sensitivity in type 2 diabetic patients. Int J Clin Pract (2003) 57(4):258-61.

119. Lind L, Pollare T, Hvarfner A, Lithell H, Sorensen OH, Ljunghall S. Longterm treatment with active vitamin $\mathrm{D}$ (alphacalcidol) in middle-aged men with impaired glucose tolerance. Effects on insulin secretion and sensitivity, glucose tolerance and blood pressure. Diabetes Res (1989) 11(3):141-7.

120. Scragg R, Holdaway I, Singh V, Metcalf P, Baker J, Dryson E. Serum 25-hydroxyvitamin D3 is related to physical activity and ethnicity but not obesity in a multicultural workforce. Aust N Z J Med (1995) 25(3):218-23. doi:10.1111/j.1445-5994.1995.tb01526.x

121. Botella-Carretero JI, Alvarez-Blasco F, Villafruela JJ, Balsa JA, Vazquez C, Escobar-Morreale HF. Vitamin D deficiency is associated with the metabolic syndrome in morbid obesity. Clin Nutr (2007) 26(5):573-80. doi:10.1016/j. clnu.2007.05.009

122. Ford ES, Ajani UA, McGuire LC, Liu S. Concentrations of serum vitamin $\mathrm{D}$ and the metabolic syndrome among U.S. adults. Diabetes Care (2005) 28(5):1228-30. doi:10.2337/diacare.28.5.1228

123. Mutt SJ, Hypponen E, Saarnio J, Jarvelin MR, Herzig KH. Vitamin D and adipose tissue-more than storage. Front Physiol (2014) 5:228. doi:10.3389/ fphys.2014.00228

124. Sakuma T, Miyamoto T, Jiang W, Kakizawa T, Nishio SI, Suzuki S, et al. Inhibition of peroxisome proliferator-activated receptor alpha signaling by vitamin D receptor. Biochem Biophys Res Commun (2003) 312(2):513-9. doi:10.1016/j.bbrc.2003.10.131

125. Duque G, Macoritto M, Kremer R. 1,25(OH)2D3 inhibits bone marrow adipogenesis in senescence accelerated mice (SAM-P/6) by decreasing the expression of peroxisome proliferator-activated receptor gamma 2 (PPARgamma2). Exp Gerontol (2004) 39(3):333-8. doi:10.1016/j.exger.2003.11.008

126. Duque G, Macoritto M, Dion N, Ste-Marie LG, Kremer R. 1,25(OH)2D3 acts as a bone-forming agent in the hormone-independent senescence-accelerated mouse (SAM-P/6). Am J Physiol Endocrinol Metab (2005) 288(4):E723-30. doi:10.1152/ajpendo.00180.2004

127. Liu P, Oyajobi BO, Russell RG, Scutt A. Regulation of osteogenic differentiation of human bone marrow stromal cells: interaction between transforming growth factor-beta and $1,25(\mathrm{OH})(2)$ vitamin $\mathrm{D}(3)$ In vitro. Calcif Tissue Int (1999) 65(2):173-80. doi:10.1007/s002239900678

128. Zhou S, LeBoff MS, Glowacki J. Vitamin D metabolism and action in human bone marrow stromal cells. Endocrinology (2010) 151(1):14-22. doi:10.1210/ en.2009-0969

129. Ortega RM, Aparicio A, Rodriguez-Rodriguez E, Bermejo LM, Perea JM, Lopez-Sobaler AM, et al. Preliminary data about the influence of vitamin D status on the loss of body fat in young overweight/obese women following two types of hypocaloric diet. Br J Nutr (2008) 100(2):269-72. doi:10.1017/ S0007114508894354

130. Ljunghall S, Lind L, Lithell H, Skarfors E, Selinus I, Sorensen OH, et al. Treatment with one-alpha-hydroxycholecalciferol in middle-aged men with impaired glucose tolerance - a prospective randomized double-blind study. Acta Med Scand (1987) 222(4):361-7. doi:10.1111/j.0954-6820.1987. tb10684.x

131. Major GC, Alarie F, Dore J, Phouttama S, Tremblay A. Supplementation with calcium + vitamin D enhances the beneficial effect of weight loss on plasma lipid and lipoprotein concentrations. Am J Clin Nutr (2007) 85(1):54-9.

132. Major GC, Alarie FP, Dore J, Tremblay A. Calcium plus vitamin D supplementation and fat mass loss in female very low-calcium consumers: potential link with a calcium-specific appetite control. Br J Nutr (2009) 101(5):659-63. doi:10.1017/S0007114508030808

133. Salehpour A, Hosseinpanah F, Shidfar F, Vafa M, Razaghi M, Dehghani S, et al. A 12-week double-blind randomized clinical trial of vitamin $\mathrm{D}(3)$ supplementation on body fat mass in healthy overweight and obese women. Nutr J (2012) 11:78. doi:10.1186/1475-2891-11-78

134. Wamberg L, Kampmann U, Stodkilde-Jorgensen H, Rejnmark L, Pedersen SB, Richelsen B. Effects of vitamin D supplementation on body fat accumulation, inflammation, and metabolic risk factors in obese adults with low vitamin D levels - results from a randomized trial. Eur J Intern Med (2013) 24(7):644-9. doi:10.1016/j.ejim.2013.03.005

135. Zhou J, Zhao LJ, Watson P, Zhang Q, Lappe JM. The effect of calcium and vitamin D supplementation on obesity in postmenopausal women: secondary analysis for a large-scale, placebo controlled, double-blind, 4-year longitudinal clinical trial. Nutr Metab (2010) 7:62. doi:10.1186/1743-7075-7-62

136. Pramyothin P, Biancuzzo RM, Lu Z, Hess DT, Apovian CM, Holick MF. Vitamin $D$ in adipose tissue and serum 25 -hydroxyvitamin $D$ after roux-en-Y gastric bypass. Obesity (2011) 19(11):2228-34. doi:10.1038/oby.2011.170 
137. Wortsman J, Matsuoka LY, Chen TC, Lu Z, Holick MF. Decreased bioavailability of vitamin D in obesity. Am J Clin Nutr (2000) 72(3):690-3.

138. Reinehr T, de Sousa G, Alexy U, Kersting M, Andler W. Vitamin D status and parathyroid hormone in obese children before and after weight loss. Eur J Endocrinol (2007) 157(2):225-32. doi:10.1530/EJE-07-0188

139. Ward KA, Das G, Berry JL, Roberts SA, Rawer R, Adams JE, et al. Vitamin D status and muscle function in post-menarchal adolescent girls. J Clin Endocrinol Metab (2009) 94(2):559-63. doi:10.1210/jc.2008-1284

140. Bischoff-Ferrari HA, Borchers M, Gudat F, Durmuller U, Stahelin HB, Dick W. Vitamin D receptor expression in human muscle tissue decreases with age. J Bone Miner Res (2004) 19(2):265-9. doi:10.1359/jbmr.2004.19.2.265

141. Vazquez G, de Boland AR, Boland RL. Involvement of calmodulin in 1alpha,25-dihydroxyvitamin D3 stimulation of store-operated Ca2+ influx in skeletal muscle cells. J Biol Chem (2000) 275(21):16134-8. doi:10.1074/ jbc.C901008199

142. Santillan G, Katz S, Vazquez G, Boland RL. TRPC3-like protein and vitamin D receptor mediate 1alpha,25(OH)2D3-induced SOC influx in muscle cells. Int J Biochem Cell Biol (2004) 36(10):1910-8. doi:10.1016/j.biocel.2004.01.027

143. Crocombe S, Mughal MZ, Berry JL. Symptomatic vitamin D deficiency among non-Caucasian adolescents living in the United Kingdom. Arch Dis Child (2004) 89(2):197-9. doi:10.1136/adc.2003.026799

144. Ladhani S, Srinivasan L, Buchanan C, Allgrove J. Presentation of vitamin D deficiency. Arch Dis Child (2004) 89(8):781-4. doi:10.1136/adc.2003.031385

145. Glerup H, Mikkelsen K, Poulsen L, Hass E, Overbeck S, Andersen H, et al. Hypovitaminosis D myopathy without biochemical signs of osteomalacic bone involvement. Calcif Tissue Int (2000) 66(6):419-24. doi:10.1007/ s002230010085

146. Bischoff HA, Stahelin HB, Dick W, Akos R, Knecht M, Salis C, et al. Effects of vitamin $\mathrm{D}$ and calcium supplementation on falls: a randomized controlled trial. J Bone Miner Res (2003) 18(2):343-51. doi:10.1359/jbmr.2003.18.2.343

147. Bischoff HA, Stahelin HB, Urscheler N, Ehrsam R, Vonthein R, PerrigChiello P, et al. Muscle strength in the elderly: its relation to vitamin D metabolites. Arch Phys Med Rehabil (1999) 80(1):54-8. doi:10.1016/ S0003-9993(99)90307-6

148. Boland R. Role of vitamin D in skeletal muscle function. Endocr Rev (1986) 7(4):434-48. doi:10.1210/edrv-7-4-434

149. Chapuy MC, Arlot ME, Duboeue F, Brun J, Crouzet B, Arnaud S, et al. Vitamin D3 and calcium to prevent hip fractures in elderly women. $N$ Engl J Med (1992) 327:1637-42. doi:10.1056/NEJM199212033272305

150. Dawson-Hughes B, Harris SS, Krall EA, Dallal GE. Effect of calcium and vitamin D supplementation on bone density in men and women 65 years of age or older. N Engl J Med (1997) 337(10):670-6. doi:10.1056/ NEJM199709043371003

151. Mowe M, Haug E, Bohmer T. Low serum calcidiol concentration in older adults with reduced muscular function. J Am Geriatr Soc (1999) 47(2):220-6. doi:10.1111/j.1532-5415.1999.tb04581.x

152. Sorensen OH, Lund B, Saltin B, Andersen RB, Hjorth L, Melsen F, et al. Myopathy in bone loss of ageing: improvement by treatment with 1 alpha-hydroxycholecalciferol and calcium. Clin Sci (1979) 56(2):157-61. doi:10.1042/ cs0560157

153. Stein MS, Wark JD, Scherer SC, Walton SL, Chick P, Di Carlantonio M, et al. Falls relate to vitamin D and parathyroid hormone in an Australian nursing home and hostel. J Am Geriatr Soc (1999) 47(10):1195-201. doi:10.111 1/j.1532-5415.1999.tb05199.x

154. Al-Said YA, Al-Rached HS, Al-Qahtani HA, Jan MM. Severe proximal myopathy with remarkable recovery after vitamin D treatment. Can J Neurol Sci (2009) 36(3):336-9. doi:10.1017/S0317167100007083

155. Bischoff-Ferrari HA, Dawson-Hughes B, Staehelin HB, Orav JE, Stuck AE, Theiler R, et al. Fall prevention with supplemental and active forms of vitamin D: a meta-analysis of randomised controlled trials. BMJ (2009) 339:b3692. doi:10.1136/bmj.b3692

156. Bischoff-Ferrari HA, Willett WC, Wong JB, Giovannucci E, Dietrich T, Dawson-Hughes B. Fracture prevention with vitamin D supplementation: a meta-analysis of randomized controlled trials. JAMA (2005) 293(18):225764. doi:10.1001/jama.293.18.2257

157. LeBoff MS, Hawkes WG, Glowacki J, Yu-Yahiro J, Hurwitz S, Magaziner J. Vitamin D-deficiency and post-fracture changes in lower extremity function and falls in women with hip fractures. Osteoporos Int (2008) 19(9):1283-90. doi:10.1007/s00198-008-0582-6
158. Manini TM, Clark BC, Nalls MA, Goodpaster BH, Ploutz-Snyder LL, Harris TB. Reduced physical activity increases intermuscular adipose tissue in healthy young adults. Am J Clin Nutr (2007) 85(2):377-84.

159. Holst D, Luquet S, Kristiansen K, Grimaldi PA. Roles of peroxisome proliferator-activated receptors delta and gamma in myoblast transdifferentiation. Exp Cell Res (2003) 288(1):168-76. doi:10.1016/S0014-4827(03)00179-4

160. Hu E, Tontonoz P, Spiegelman BM. Transdifferentiation of myoblasts by the adipogenic transcription factors PPAR gamma and C/EBP alpha. Proc Natl Acad Sci U S A (1995) 92(21):9856-60. doi:10.1073/pnas.92.21.9856

161. Vettor R, Milan G, Franzin C, Sanna M, De Coppi P, Rizzuto R, et al. The origin of intermuscular adipose tissue and its pathophysiological implications. Am J Physiol Endocrinol Metab (2009) 297(5):E987-98. doi:10.1152/ ajpendo.00229.2009

162. Ahmed W, Khan N, Glueck CJ, Pandey S, Wang P, Goldenberg N, et al. Low serum $25(\mathrm{OH})$ vitamin D levels $(<32 \mathrm{ng} / \mathrm{mL})$ are associated with reversible myositis-myalgia in statin-treated patients. Transl Res (2009) 153(1):11-6. doi:10.1016/j.trsl.2008.11.002

163. Pfeifer M, Begerow B, Minne HW, Abrams C, Nachtigall D, Hansen C. Effects of a short-term vitamin $\mathrm{D}$ and calcium supplementation on body sway and secondary hyperparathyroidism in elderly women. J Bone Miner Res (2000) 15(6):1113-8. doi:10.1359/jbmr.2000.15.6.1113

164. Sato Y, Iwamoto J, Kanoko T, Satoh K. Low-dose vitamin D prevents muscular atrophy and reduces falls and hip fractures in women after stroke: a randomized controlled trial. Cerebrovasc Dis (2005) 20(3):187-92. doi: $10.1159 / 000087203$

165. Yoshikawa S, Nakamura T, Tanabe H, Imamura T. Osteomalacic myopathy. Endocrinol Jpn (1979) 26(Suppl):65-72. doi:10.1507/endocrj1954.26. Supplement_65

166. El-Hajj Fuleihan G, Nabulsi M, Tamim H, Maalouf J, Salamoun M, Khalife $\mathrm{H}$, et al. Effect of vitamin D replacement on musculoskeletal parameters in school children: a randomized controlled trial. J Clin Endocrinol Metab (2006) 91(2):405-12. doi:10.1210/jc.2005-1436

167. Wren TA, Kim PS, Janicka A, Sanchez M, Gilsanz V. Timing of peak bone mass: discrepancies between CT and DXA. J Clin Endocrinol Metab (2007) 92(3):938-41. doi:10.1210/jc.2006-1570

168. Lee DC, Gilsanz V, Wren TA. Limitations of peripheral quantitative computed tomography metaphyseal bone density measurements. J Clin Endocrinol Metab (2007) 92(11):4248-53. doi:10.1210/jc.2007-0126

169. Bolland MJ, Grey AB, Ames RW, Horne AM, Gamble GD, Reid IR. Fat mass is an important predictor of parathyroid hormone levels in postmenopausal women. Bone (2006) 38(3):317-21. doi:10.1016/j.bone.2005.08.018

170. Bolland MJ, Grey AB, Gamble GD, Reid IR. Association between primary hyperparathyroidism and increased body weight: a meta-analysis. J Clin Endocrinol Metab (2005) 90(3):1525-30. doi:10.1210/jc.2004-1891

171. Ponrartana S, Aggabao PC, Hu HH, Aldrovandi GM, Wren TA, Gilsanz V. Brown adipose tissue and its relationship to bone structure in pediatric patients. J Clin Endocrinol Metab (2012) 97(8):2693-8. doi:10.1210/ jc.2012-1589

172. Bredella MA, Gill CM, Rosen CJ, Klibanski A, Torriani M. Positive effects of brown adipose tissue on femoral bone structure. Bone (2014) 58:55-8. doi:10.1016/j.bone.2013.10.007

173. Gilsanz V, Chung SA, Jackson H, Dorey FJ, Hu HH. Functional brown adipose tissue is related to muscle volume in children and adolescents. J Pediatr (2011) 158(5):722-6. doi:10.1016/j.jpeds.2010.11.020

174. Bredella MA, Fazeli PK, Freedman LM, Calder G, Lee H, Rosen CJ, et al. Young women with cold-activated brown adipose tissue have higher bone mineral density and lower Pref-1 than women without brown adipose tissue: a study in women with anorexia nervosa, women recovered from anorexia nervosa, and normal-weight women. J Clin Endocrinol Metab (2012) 97(4):E584-90. doi:10.1210/jc.2011-2246

175. Gilsanz V. Bone density in children: a review of the available techniques and indications. Eur J Radiol (1998) 26(2):177-82. doi:10.1016/ S0720-048X(97)00093-4

176. Hu HH, Nayak KS. Change in the proton T(1) of fat and water in mixture. Magn Reson Med (2010) 63(2):494-501. doi:10.1002/mrm.22205

177. Kovanlikaya A, Mittelman SD, Ward A, Geffner ME, Dorey F, Gilsanz $\mathrm{V}$. Obesity and fat quantification in lean tissues using three-point Dixon MR imaging. Pediatr Radiol (2005) 35(6):601-7. doi:10.1007/ s00247-005-1413-y 
178. McNeill G, Fowler PA, Maughan RJ, McGaw BA, Fuller MF, Gvozdanovic D, et al. Body fat in lean and overweight women estimated by six methods. $\mathrm{Br} \mathrm{J}$ Nutr (1991) 65(2):95-103. doi:10.1079/BJN19910072

179. Seidell JC, Bakker CJ, van der Kooy K. Imaging techniques for measuring adipose-tissue distribution - a comparison between computed tomography and 1.5-T magnetic resonance. Am J Clin Nutr (1990) 51(6):953-7.

180. Glover GH, Schneider E. Three-point Dixon technique for true water/fat decomposition with B0 inhomogeneity correction. Magn Reson Med (1991) 18(2):371-83. doi:10.1002/mrm.1910180211

181. Hardy PA, Hinks RS, Tkach JA. Separation of fat and water in fast spin-echo MR imaging with the three-point Dixon technique. J Magn Reson Imaging (1995) 5(2):181-5. doi:10.1002/jmri.1880050213

182. Kovanlikaya A, Guclu C, Desai C, Becerra R, Gilsanz V. Fat quantification using three-point Dixon technique: in vitro validation. Acad Radiol (2005) 12(5):636-9. doi:10.1016/j.acra.2005.01.019

183. Xiang QS. Two-point water-fat imaging with partially-opposed-phase (POP) acquisition: an asymmetric Dixon method. Magn Reson Med (2006) 56(3):572-84. doi:10.1002/mrm.20984

184. Hu HH, Kim HW, Nayak KS, Goran MI. Comparison of fat-water MRI and single-voxel MRS in the assessment of hepatic and pancreatic fat fractions in humans. Obesity (2010) 18(4):841-7. doi:10.1038/oby.2009.352

185. Reeder SB, McKenzie CA, Pineda AR, Yu H, Shimakawa A, Brau AC, et al. Water-fat separation with IDEAL gradient-echo imaging. J Magn Reson Imaging (2007) 25(3):644-52. doi:10.1002/jmri.20831

186. Reeder SB, Pineda AR, Wen Z, Shimakawa A, Yu H, Brittain JH, et al. Iterative decomposition of water and fat with echo asymmetry and least-squares estimation (IDEAL): application with fast spin-echo imaging. Magn Reson Med (2005) 54(3):636-44. doi:10.1002/mrm.20624

187. Louis O, Fierens Y, Strantza M, Luypaert R, de Mey J, Cattrysse E. Using magnetic resonance for predicting femoral strength: added value with respect to bone densitometry. Biomed Res Int. (2015). 2015:801518. doi:10.1155/2015/801518

188. Hogler W, Blimkie CJ, Cowell CT, Kemp AF, Briody J, Wiebe P, et al. A comparison of bone geometry and cortical density at the mid-femur between prepuberty and young adulthood using magnetic resonance imaging. Bone (2003) 33(5):771-8. doi:10.1016/S8756-3282(03)00266-7

189. Schmid J, Magnenat-Thalmann N. MRI bone segmentation using deformable models and shape priors. Med Image Comput Comput Assist Interv (2008) 11(Pt 1):119-26.

190. Thomas EL, Saeed N, HajnalJV,Brynes A, Goldstone AP, Frost G, et al. Magnetic resonance imaging of total body fat. J Appl Physiol (1998) 85(5):1778-85

Conflict of Interest Statement: The authors declare that the research was conducted in the absence of any commercial or financial relationships that could be construed as a potential conflict of interest.

Copyright (c) 2016 Kremer and Gilsanz. This is an open-access article distributed under the terms of the Creative Commons Attribution License (CC BY). The use, distribution or reproduction in other forums is permitted, provided the original author(s) or licensor are credited and that the original publication in this journal is cited, in accordance with accepted academic practice. No use, distribution or reproduction is permitted which does not comply with these terms. 